\title{
Kaizen: Quality Improvement Innovation Higher Education in the Industrials Revolution 4.0
}

\author{
Achmad Supriyanto \\ Department of Educational Administration \\ Universitas Negeri Malang, Indonesia \\ a.supriyanto.fip@um.ac.id
}

\author{
Rochmawati \\ Department of Educational Management \\ Postgraduate, Universitas Negeri Malang, Indonesia \\ rara.pinkiesty@gmail.com
}

\author{
Djum Djum Noor Benty \\ Department of Educational Administration \\ Universitas Negeri Malang, Indonesia \\ djum.djum.fip@um.ac.id
}

\begin{abstract}
The digitally global era of the 4.0 industrial revolution is the key in the quality of educational institutions, in this context Higher Education (PT). The concept of quality education that addresses the delivery of services and products is an important part of the process and is sustainable in a sustainable manner. Quality plays a role in PT. The purpose of this study is to increase the achievement of tertiary institutions through an innovative strategy, namely Kaizen, which focuses on efforts to minimize the initial error (zero defect) in the management process of higher education. This research uses qualitative by designing descriptive analysis study. Based on the research, it was concluded that Kaizen focuses on continuous and continuous quality improvement (continuous improvement), oriented towards improving the culture of quality educational institutions. In the process it leads to the quality of productivity as a form of improvement, improvement, and improvement in the quality of education. Orientation, trying to create a culture of educational institutions needs to be prioritized. Kaizen concept as zero defect.
\end{abstract}

Keywords: kaizen, quality, higher education, industrial revolution era 4.0

\section{INTRODUCTION}

The Industrial Revolution Era 4.0 becomes an urgent and vital thing that must be faced in the millennial era. Educational institutions in this context Higher Education (PT) as the birth-generation $\mathrm{Z}$ generation must be able to have an adequate level of relevance and quality in the administration of education. Tresya (2019), argues that the 4.0 Industrial Revolution will bring many changes with all the consequences, the industry will be more compact and efficient. But there are also risks that might arise, for example the reduction in Human Resources due to being replaced by machines. This is in line with the presentation of Schwab (2017), now we are at the beginning of a revolution that fundamentally changes the way of life, work and relate to one another. Dardak (2019), the reason to say that the 4.0 industrial revolution is in full force today is due to the fact that velocity and the impact of current breakthroughs is like never before. Martin (2019), there are three key areas where human beat machines that are key to future job creation are: (1) creative endeavors; (2) social interaction; and (3) physical dexterity and mobility. The exposure indicated that the industrial revolution of the 4.0 era had a very significant influence and impact on life, including in the field of education.

Educational institutions as a vehicle for producing quality, superior, and characterized academic community members have become a necessity in the management system to prioritize quality-based principles. In essence, the quality or quality of educational institutions becomes crucial that their existence needs to be prioritized and continually improved. Basically, quality is the key to success and as an embryo of improving the quality of a nation. Sallis (2008), argues that the basic concept of quality is absolute and relative. Absolute quality is a high idealism quality and must be met. While relative quality is that quality is not an attribute of a service product, but something that is ascribed to the product or service. Arcaro (2007), argues that quality as a structural process to improve the output produced. That is, quality is the result of a process that is systematically capable of producing something of quality. Gallardo and Gregory (2019), quality is oriented toward adjusting customer needs and desires (need and desire) by designing products and services that meet and satisfy customer expectations. Because the main purpose of quality is customer satisfaction (customer satisfaction). The presentation indicated that quality must be based on predetermined standards. Salim (2013) states that the process component is vital in improving the quality of education, the practice includes teaching, training, mentoring, evaluating, extracurricular, and managing. Furthermore, the output includes knowledge, personality, and performance.

The role of tertiary institutions as agents of change for the generation of the nation must be able to be oriented towards the future. Reamer (2019), the visionary role as an effort to produce quality educational products should be able to accommodate PT through empowering its human resources. This is stated in Law Number 12 of 2012 on Higher Education, article 4 states that the function of education is: (1) developing competence and shaping character and becoming a civilized and intelligent nation; (2) developing the academic community with character and competitiveness, cooperating through the implementation of teaching, research, and service; and (3) develop science and technology and prioritize human values. Mishra \& Kushwara (2016), higher education and particularly university education is recognized as a key force for modernization and development. In a sense, 
quality is the result of a process that is systematically capable of producing something of quality. To be qualified in pursuing quality higher education as the basis for realizing its ideals and relevance to the era of industry 4.0, Juabir (2019), for staying relevant in Industry 4.0 must be able to adapt and innovate that results in achievement. To be able to produce achievements, of course, tertiary institutions need a management system based on quality education. Human Resources (HR) as the implementer of a system or policy is appropriate and should emphasize on the conception of quality. Because, the excellence factor to realize its realization is HR as a concentration of talent wherein the improvement in productivity of the quality of human resources is a key instrument and priority makes it happen.

Based on the explanation, universities have a very strategic role in producing reliable, creative and quality human resources. In this context, the system to produce quality is more emphasized on the prevention of errors from the beginning (zero defect), not merely on evaluation and the process is carried out in continuous improvement. As a fool and innovation related to improving the quality of higher education in the industry 4.0 era, innovation in its management, Kaizen is needed. Imai (2001) states that Kaizen is derived from the word 'Kai' which means to change and 'Zen' which means better. In simple terms, Kaizen is a continuous improvement effort to be better than the current condition with the main goal is to eliminate waste that does not provide added value of products / services from the perspective of education customers (stakeholders). According to Lisetski \& Zemlyyakova (2015), kaizen is an approach to continuous improvement. In a sense, improvement little by little (step by step improvement). The philosophy is that schools as service organizations are not only about input, output, or outcome but about process. Tanaka (2017), Kaizen is an improvement which is centered on continuous process improvement actions and emphasizes that the processing stage must be improved so that results can improve, so it can be concluded that this philosophy prioritizes the process. Rochmawati (2013), kaizen emphasis on two main concepts, namely the philosophy of continuous improvement, and relates to the tools and techniques used in quality improvement to achieve customer needs and expectations. All forms of improvement are always encouraged and empowered on an ongoing basis by involving all school personnel as implementers of a system or model. According to Chadwick (2018), kaizen is a unifying tool for philosophy, systems, and tools for solving problems. In practice, it starts with realizing that every organization has a problem and a problem-solving process by forming an organizational culture where each individual can raise problems he feels freely.

At the practical level of kaizen based on quality standards, in the context of education the standard quality standards in the administration of education refer to Government Regulation No. 13 of 2015 concerning National Education Standards (SNP) and refer to the Higher Education National Accreditation Board (BANPT). In practice, Kaizen in the analysis of the emergence of problems in the implementation of education based on Fishbone Diagrams is a structured visual list that illustrates various causes that affect the process by separating and connecting one cause with another. Sukhobska (2018), the process of identification by looking for root causes that influence the process of improvement and quality improvement of indicators: (1) manpower; (2) method; (2) materials; (4) machine; and (5) environment as an indicator described as a small bone. While the big bones are the results of the analysis of the root problems of the 5 indicators, which are the root of the problem (the big bone that goes to the head) which is quality productivity. Enggasari (2007), this tool is used when an institution or team needs to identify and explore the causes of problems or look for factors that can lead to an improvement and quality improvement. If the problem and cause are known with certainty, then actions and corrective steps will be easier to do. Tomashke (2017), problem solving through fishbone can be done individually with top management or with cooperation. The process, PDCA system (plan, do, check, action) is attached to the evaluation system for individual and perpart performance. All are frameworks for continuous improvement implementation. Overall implementation of Kaizen directly touches the quality improvement process through identifying problems and finding solutions aimed at improving school quality.

This study aims to describe the implementation of Kaizen as an innovation strategy to improve the quality of tertiary institutions in the era of the industrial revolution 4.0 in supporting the credibility and accountability of tertiary institutions to meet the objectives to be achieved in the form of customer satisfaction by always prioritizing the principle of zero defect in order to create quality universities.

\section{METHOD}

This research uses descriptive analysis method, trying to understand the phenomenon that occurs in terms of the perspective of the research subject. The location of this research was conducted at Higher education. The presence of researchers as key instruments is absolutely necessary in the field, because it directly interacts with the research object.

Sources of data obtained through various techniques, including: (1) observation; (2) interviews; (3) and documentation. Data collection is done through rechecking data, and organizing data. The data analysis stage is through data reduction, data display and data verification. To maintain the validity of the data, it is done by using four criteria, including: (1) credibility; (2) transparency; (3) dependability; and (4) confirmability.

\section{RESULT AND DISCUSSION}

As a result of this research, universities in their management and implementation processes need innovative strategies to realize quality improvement. As a printing agency for the nation's next generation, the university's organizational system must be a priority for improvement. Christopher (2013), as a strategic step for universities in supporting their quality improvement, then Kaizen was conceived as a model of quality improvement. Deming in Bush and Mariane (2006), states the ever-changing quality criteria associated with products, services, people, processes, and the 
environment. Quality that always changes must always be improved according to the times, because the quality is not only at this time but for the future. Chan \& Zang (2018), digitally system has become a global necessity and the role of high traveling as a key creator of civilization formation. Puamao and Teasdale (2017), to support the university system a quality improvement strategy must be applied as the basis for the systemic relevance of improvement.

A superior university certainly cannot be separated from the key element of success, namely quality. Based on the Government Regulation of the Republic of Indonesia Number 13 Year 2015 concerning National Education Standards (SNP), Article 2 paragraph 1 expressly states that the scope of educational standards includes: content standards, process standards, graduate competency standards, educator and education personnel standards, facilities standards and infrastructure, management standards, financing standards, and education assessment standards. This means that in the process of providing education, it must meet the standards that have been legally established by the government as a concrete manifestation of the realization of the achievement of the quality of education in accordance with established standards. This is confirmed by Article 3 which states that "national education standards serve as a basis in the planning, implementation and supervision of education in order to realize quality national education. Reviewing the policy, of course, as an effort to improve the quality of each educational institution is obliged to implement the process of implementing education based on established standards, as a tangible manifestation of education quality.

Stuart (2018), Higher Education is categorized from several things, namely: (1) results, (2) process, (3) strategy, and (4) culture. The results of this study, an educational institution is said to be of quality when it is able to meet or even exceed the quality standards that have been determined and, in the process, will certainly always be done systematically and sustainably. Next is the process, which includes leadership and amendments, educational and learning practices, resources, and support from stakeholders. Chen (2010), Kaizen's strategy as an innovative step in improving its quality is based on zero defects. While in terms of culture, Zhelanova (2019), the ability to implement and habituate the values of quality and character embedded in a college. These improvements can be maximized when using the Kaizen innovation strategy based on the Fishbone Diagram. Khaer (2010), Fishbone Diagrams are practical and guide each team to keep thinking about finding the main cause of a problem. This is true if when an institution or team needs to identify and explore the causes of a problem or look for factors that lead to improvement. Pujianto (2012), Kaizen at educational institutions is able to be the driving force of the quality improvement process. Through the PDCA system, which is inherent in every management process, it becomes a central control system for comprehensive improvement.

Michael (2018), Kaizen as an innovative strategy in improving the quality of higher education has been able to become a pioneer model in accommodating characteristics in the era of the industrial revolution including digitization, optimization and customization of production, automation and adaptation, interaction between humans and machines, value added services and business, automatic data exchange and communication, and the use of information technology. Robert \& Kyne (2018), education as a systemic and systemic is able to continuously improve its quality when based on the management of the education system that is based on Kaizen based on Kaizen which emphasizes on the principle of zero defects. Wiyono (2019) suggested that the quality of education is influenced by the potential of students, the professionalism of educators and teaching staff, learning facilities, and organizational culture. Based on this, Kaizen as an innovative strategy in improving the quality of tertiary institutions has been able to analyze the existing constraints that can interfere with the process of providing quality-based education. McGrey (2019), kaizen as a comprehensive development strategy that refers to the quality development that is carried out continuously as a form of its existence in the world of education. As one of the efforts to develop quality, the Kaizen process has been identified to be continuously empowered in producing quality generation of the nation, human resources who are always willing to learn, effective teamwork, and a culture of school quality with a conducive climate. This is a form of consistency in providing quality education services.

The implementation of Kaizen as an innovative and strategic step in improving the quality of higher education is able to solve the problems faced in the implementation of integrated schools completely through the discovery of root causes and find solutions as a form of continuous quality improvement (continuous improvement. Efforts through the Kaizen model that emphasizes on improving the quality of education continuously and continuously which is oriented to the effort to create a culture of school quality, its practice with the Fishbone Cause and Effect Diagram as a media in identifying problems that cause influences the quality of education based on indicators including: (a) manpower; (b) method, (c) materials, (d) machine, and (e) environment that leads to quality productivity as a form of improvement, improvement, and development of educational quality Fishbone cause and effect diagrams as focus oriented because in addition to being easy to apply this tool too can structurally identify problems that can affect the quality of quality management institutions, of course, must empower all functions and elements involved therein, and this is indirectly as a concrete form of comprehensive quality improvement and development by prioritizing total quality of management. The implementation process involves all components of the school and stakeholders.

Kaizen as an innovative strategy underlies tertiary institutions to continuously improve their quality. The basic orientation of implementation is gradual and planned through various corrective and quality improvement measures. Imai (2005), states that the first step of Kaizen is to implement the PDCA (Plan, Do, Control, and Act) cycle as a means of ensuring the sustainability of Kaizen. This is useful in realizing policies to maintain and improve or improve standards. The implementation process starts at: increasing product 
quality (quality productivity), the process is by increasing the quality of products produced and services implemented for customer satisfaction (customer satisfaction); the strength of Human Resources (manpower), the quality / quality of human resources is one of the intense aspects in the process of improving and improving a quality. The role of human resources is very significant in a process of activities. Its existence as a small bone has a significant effect on the success of the quality to be achieved supported by the existence of education (education) and encouragement (motivation) to constantly develop to improve its quality; way (method), is a small bone that affects the quality of achievement described large bones.

This method refers to Government Regulation Number 13 of 2015 calm National Education Standards (SNP) and governance system of implementation; material (material), in the form of natural resources and facility capabilities, research must always be done to identify errors and omissions from the beginning according to the Kaizen implementation principle that seeks to minimize errors from the start (zero defects); tools (machines), information technology networks which are an intense part of the process of improving and improving the quality of schools. The use of diverse learning methods based on information technology is certainly a very significant driving factor for the improvement and improvement of the quality of education services; and the environment (environment), influenced by internal and external conditions and temperature.

Based on the Kaizen concept which is a learning journey by learning the process and finding ways to improve it. Rochmawati (2016), meaningfully indicates a better change that is made based on the culture of the organization where each person issues freely. Kaourahida (2018), Kaizen supports the level of freedom of over repair by preventing mistakes from the beginning in the existing process with the main goal of continuous improvement efforts. When, everything is based on a quality process of course the results to be obtained are also of good quality. Its essence when in the process there are no mistakes from the beginning of course the process in order to produce a product will have high quality. Megumi (2018), Kaizen segmentation is oriented to: management, in this context the management of organizing and individuals as the main orientation.

The results of the analysis and solutions to the root problems found in the Kazien implementation process are: (1) the concept of quality culture that still feels strange. This is indicated from the factors of discipline, climate, and also regulation as an umbrella of school policy; (2) diverse levels of HR competencies; and (3) the links of national and international cooperation that need to be maximally improved. Alternative ways to overcome the inhibiting factors include: (a) promoting quality-based services, quality culture as a result of daily habituation prioritizing quality will be an innovative step towards creating a school quality culture; (b) Forming team work by implementing the $3 \mathrm{M}$ Kaizen concept according to Imai (2005), namely Youth, reducing waste or waste; Mura, difference reduction, in this context the alternative used is the presence of options for the use of the type of product; and Muri, reducing tension and further strengthening relations between school personnel; and (c) establishing cooperative links with parties on a local, national and international scale.

Supporting factors at this school include: (1) HR readiness, in terms of high willingness (enthusiasm) despite having limited abilities. This is indicated from the beginning researchers conducted a preliminary study at the school. The enthusiasm and determination to progress, excel, and become the best is indicated from the tenacity and enthusiasm of each personnel. In addition, the commitment of top management becomes one of the strengths in fostering the spirit and tenacity of HR; collaboration between researchers and the school is not only limited to research but also sharing insights and also participating in several school activities; information technology, as an asset supporting communication. Because in essence the world will continue to evolve according to the demands of increasingly complex times as one of the factors of change, namely through the use of technology and information as media in the process of minimizing concrete distances; and (2) proper use of technology. Empowerment or empowerment of supporting factors is carried out as an effort to maximize and optimize various programs to improve the quality of existing school services.

So that the process can run optimally and optimally, the empowerment includes: (1) involving the HR component at school and all stakeholders, a form of the Kaizen process which conceptually views that the process of improvement always involves all components from the operator level to top management; (2) optimization of cooperation links and interchange relations. An interchangeable and symbiotic mutualism relationship underlies the process of cooperation; the use of print and electronic media as support for effective communication, is very significant in the Kaizen implementation research process; and (3) the use of information technology both print and electronic media as a support for effective communication, is very significant in the process of research and development of the Kaizen model. The use of media is not limited to the use of printbased media such as documents and so on. The model is promoted in an effort to improve the quality of school management based on quality culture. The goal is to produce quality generation of the nation, human resources who are always willing to learn, teamwork cohesiveness, and the existence of a school quality culture so that they can build an image of quality as a form of consistency in the quality of education.

Based on the explanation, improving the quality of higher education through the implementation of Kaizen is a strategic framework and innovation in the quality of education productivity. The Fishbone Cause and Effect Diagram tool is a powerful media in the process of maximizing quality, because it identifies factors related to quality comprehensively. The process is continuous / continuous (continuous improvement) for customer satisfaction. As a form of customer satisfaction, a public trust is created that definitely stimulates the existence of schools. Considering that quality is the key to a successful program, of course the involvement of the HR component and all education stakeholders needs to be constantly 
carried out in order to achieve optimal and comprehensive quality.

\section{CONCLUSION}

The implementation of Kaizen as an innovation to improve the quality of higher education in the 4.0 era is a priority. Efforts to improve the quality of these are carried out in a continuous improvement and are a strategic step in meeting customer needs and desires. The zero-defect principle is emphasized in this regard. Considering that quality is absolute and relative, so its existence needs to be improved continuously and continuously.

Kaizen is a strategic framework for efforts to improve the quality of education services and the quality of graduates or products aimed at customer satisfaction. The orientation of model development as a strategic effort in the process of improving the quality of education, emphasizes continuous process improvement. The tools are practical in guiding each team to keep thinking about finding the main cause of a problem.

In the implementation process, it is used to identify the factors that cause the problem and identify the factors that are related to the problem, look for the root of the problem and find solutions to overcome it. The factors that become obstacles and support for their existence are viewed from an internal perspective, and alternative ways are sought to minimize the inhibiting factors and efforts to empower supporting factors as a concrete form of improving the quality of higher education.

\section{REFERENCES}

[1] Arcaro, J.S. 2007. Quality in Education: An Implementation Handbook. Yogyakarta: Pustaka Belajar.

[2] Bush, T., \& Marianne. C. 2006. Manajemen Strategis Kepemimpinan Pendidikan. Yogyakarta: IRCiSoD.

[3] Chadwick, A. 2018. Kaizen: Interaction Citizen Millenium. International Journal of Policy, Andministration and Institutions, 16, 271-300.

[4] Chan, P. W. K., \& Zhang, H. 2018. Introduction: Dialogues about the Local and the Global in Education. The International Education Journal: Comparative Perspectives, 17(3), 1-4.

[5] Chen, K. H. 2010. Kaizen as a Method: Toward deimperialization. Durham, NC: Duke University Press.

[6] Christopher, L. C. 2013. Understanding Digitaly System in Higher Education. Analysing Publishing Technologies, 7(11), 1-8.

[7] Dardak, E. E. 2019. Characteristics of Education in the Industrial Revolution Era 4.0. Presented at the National Seminar on Education Management Study Program, State University of Malang.

[8] Enggasari, N. 2007. Building Quality through Information Strategy and Supply Chan Management in the CPO Industry. Yogyakarta: Universitas Gajah Mada (UGM).

[9] Gallardo, R., and Gregori, E. 2018. Community Development in the Digitale Age: Role of Extebntion. Journal of Extention, 56(4), 1-7.

[10] Government Regulation Number 13 Year 2015 Regarding National Education Standards. Jakarta: Fokus Media.

[11] Imai, M. 2001. Kaizen (Ky'zen) The Key to Japanese Success in Competition. Jakarta: PT Pustaka Binaman Presindo.
[12] Imai, M. 2005. Gemba Kaizen A Commonsense Approach to A Continuous Improvement Strategy. New York: Penguin.

[13] Jubair, F. 2019. Staying Relevant In Industrial 4.0. Papers presented at the National Seminar on Education Management Study Program, State University of Malang.

[14] Kaourohida, T. 2018. Kaizen: Approach Strategi Inovative in Education. Tokyo: Hanagawa Corp.

[15] Khaer, M. 2010. Fishbone Kaoru Ishikawa Sebagai Alat Pengendali Mutu. Retrieved 2 June 2019, from http://www.google.com/miftah19.files.wordpress.com/201 $0 / 06 /$.

[16] Law Number 12 of 2012 concerning Higher Education. Jakarta: Fokus Media.

[17] Lisetski, F., \& Zemlyakova, A. 2015. Kayzen Strategy For Quality. Procedia - Social and Behavioral Sciences, 214(6), 183-191.

[18] Martin, A. 2019. Speech oh the Future of the Community Sector. Hampshire, UK: Palgrave Macamillan

[19] McGer, Y. U. 2019. Global Transformations of the Education. International Perspective on Bernstine Sociology of education Research Journa , 1-19.

[20] Megumi, P. L. 2018. Co-Opertaional Sysytem in Quality Improvement. Paris:OECD

[21] Mishra, B., and Kushwaha, G. S. 2016. A Review of Quality Factors of Higher Education. IOSR Journal of Research \& Method in Education (IOSR-JRME), 6(5), 6268.

[22] Puamau, P. Q., \& Teasdale, G. R. 2007. International Handbook of Urban Education. Dordrecht: Springer.

[23] Pujianto, S. N. 2012. Implementasi Kaizen pada Budaya Mutu Perusahaan di Indonesia (Studi Kasus Budaya Mutu Continouns Improvement di BINUS University). Retrieved 2 June 2019, from http://www.sitapujianto.blogspot.com/.

[24] Reamer, F. G. 2019. The Digital and Electronic Revoluition to Quality Improve in Higher Education. Journal of Africa Aisan Local Government Studie, 1(3), 128.

[25] Robert, K. L., \& Kyne. P.K. 2018. Develophing a Paedagogy of Mutuality in a Capability Approach: Kaizen Models. Open Educational Resources (OER) of the Teacher Education. International Journal of Education Development, 33(3), 263-271.

[26] Rochmawati. 2013. Development of the Kaizen Model with the Fishbone Cause and Effect Diagram Tool for Improving the Quality of the Integrated Bojonegoro Model School. Thesis: Program Studi Management Pendidikan, State University of Malang.

[27] Rochmawati. 2016. The Implementation of Kaizen based on Fishbone Cause and Effect Diagram for Upgrading Quality of Schools with Continuous Improvement. Oral Presenattion APEC/ICER. International Conference on Education Research Khon Kaen, Thailand November 12152016

[28] Salim, S. 2013. Quality of Education Through the Learning Process. Retrieved 3 June 2019, form http://www.sambasalim.com/pendidikan/kualitas.html.

[29] Sallis, E. 2008. Total Quality Management in Education. Yogyakarta: IRCiSOD.

[30] Schwab, K, M. 2017. The Fourth Industrial Revolution. Retrieved 3 June 2019, form https://www.weforum.org/about/klaus-schwab.

[31] Stuart, K. L. 2018. Quality Approach: Global Phenomenon or Cultural Guise. The International Education Journal: comparative Perspective, 17(3), 1529.

[32] Sukhobska, Y. K. 2018. Fishbone Cause and Effect Diagram: Quality Approach. NC: Duke University Press. 
[33] Tanaka, K. R. 2017. Kaizen: The Concept of Empowerment, Helping Communities to Help Themselves. Retrieved 3 June 2019, from http://www.theblog.com.

[34] Tomaske, N. 2018. System Coaching Quality Approve: Fishbone Diagram. Journal of Vasyl Stefanyk Precarpathian National University, 6(1), 43-52.

[35] Tresya, V. 2019. Industrial Revolution 4.0: Definition, Principles, and Challenges of Millennial Generation.
Retrieved 3 June 2019, form https://www.maxmanroe.com/revolusi-industri-4-0.html.

[36] Wiyono, B. B. 2019. Manajemen Pendidikan di Era Revolusi Industri 4.0 (Peluang dan Tantangan). Malang: Universitas Negeri Malang.

[37] Zhelanova, V. 2019. Formation of Complete Reflex Constructions of Future Pedagogue in the Educational Environment of Higer Education. Journal of Vasyl Stefanyk Precarpathian National University, 6(1), 28-36. 